\title{
The Effects of Evaporative Cooling on Heat Stressed Dairy Holstein Cows Under a Semi-Arid Environment in Riyadh Area, Saudi Arabia
}

\author{
Mohamed Jafar Al-Hassan \\ Department of Animal Production, College of Food and Agriculture Sciences, King Saud University, Riyadh, Saudi Arabia
}

Email address:

mjalhassan@gmail.com

\section{To cite this article:}

Mohamed Jafar Al-Hassan. The Effects of Evaporative Cooling on Heat Stressed Dairy Holstein Cows Under a Semi-Arid Environment in Riyadh Area, Saudi Arabia. Animal and Veterinary Sciences. Vol. 6, No. 5, 2018, pp. 67-73. doi: 10.11648/j.avs.20180605.11

Received: September 7, 2018; Accepted: September 25, 2018; Published: October 24, 2018

\begin{abstract}
Heat stress has been identified as a major cause of lower productive and reproductive performance in animal farming. Methods for protecting livestock from heat stress were investigated during the summer months, where one six Holstein cows kept under shade only (group 1), and another six cows kept under shade with evaporative cooling (group 2). The results show that shade and water sprayers (evaporative cooling) significantly lowered ambient temperature and thus reduced the heat stress experienced by dairy cows in Saudi Arabia. Evaporative cooling plus shade, lowered ambient temperature $\left(41.80 \pm 0.74\right.$ vs. $\left.47.40 \pm 0.84^{\circ} \mathrm{C}\right)$, increased relative humidity $(0.33 \pm 0.01$ vs. $0.24 \pm 0.01)$ and decreased the temperature humidity index $(80.24 \pm 0.60$ vs. $84.77 \pm 0.68)$ when compared to shade alone. In addition, cows kept under evaporative cooling $\left(38.4 \pm 0.32^{\circ} \mathrm{C}\right)$ experienced lower rectal temperatures compared to cows under shade alone $\left(39.53 \pm 0.44^{\circ} \mathrm{C}\right) . \mathrm{Cows}$ under evaporative cooling had higher serum concentrations of triidothyronine $(2.50 \pm 0.90 \mathrm{vs} .0 .75 \pm 0.20 \mathrm{ng} / \mathrm{ml})$ and thyroxine $(11.94 \pm 1.60$ vs. $7.22 \pm 1.88)$ than cows under shade alone. Thus, evaporative cooling can decrease the heat stress experienced by dairy cows in Saudi Arabia and limit its associated detrimental effects.
\end{abstract}

Keywords: Dairy Cows, Evaporative Cooling, Ambient Temperature, Rectal Temperature, Relative Humidity, Temperature Humidity Index, Triidothyronine, Thyroxine

\section{Introduction}

Desert environments have high daytime temperatures and solar radiation levels during the summer months [1]. More than half of Saudi Arabia is desert land, and the average summer temperature reaches $43^{\circ} \mathrm{C}$, and can often hit a high of $54^{\circ} \mathrm{C}[2,3]$.

The detrimental effects of heat stress on dairy cows during summer months are well documented [4, 5]. Heat stress induces changes in dairy cows' respiration rate, heart rate, sweating, blood chemistry, and hormone levels $[5,6]$. In addition, heat stress increases the rectal and core body temperatures of dairy cows $[7,8]$.

Rectal temperature and core body temperature of dairy cows are positively correlated [8]. Increased body temperature reduces uterine blood flow $[9,10]$ leading to an increased uterine temperature, resulting in a decrease in fertility because of an unfavorable uterine environment for successful insemination. Environmental heat stress triggers blood flow changes that direct the flow of blood away from the uterus, thereby interfering with the nutrients and hormones supplied to the conceptus, thus damaging or killing the developing embryo [11]. Research has shown that cooled Holstein dairy cows have higher blood flow to the ovaries during estrus near ovulation than control group, which may contribute to improved fertility in dairy cows [12].

Even for a short period, the effects of heat stress on dairy cows in general, and especially in arid and semi-arid regions, include reduction in milk production and number of births $[13,14]$. Heat stress compromises follicular development, steroidogenesis and oocyte quality [11], increases early embryonic death and days open, and prolongs days to first service, number of inseminations per pregnancy and calving interval $[15,16]$. Stress responses to summer conditions are especially severe, and diurnal patterns of rectal temperature seldom return to the thermoneutral zone [7]. 
Dairy farms respond to heat stress by providing shade and evaporative cooling. Cooling should improve reproductive performance, provided that it adequately lowers body temperature. Dairy cows are known to suffer from heat stress at a temperature humidity index (THI) greater than 70-72 [17], which reduces milk production proportionally to rectal temperature [18].

The hypothalamus regulates the secretion of triidothyronine (T3) and thyroxine (T4), which in turn, inhibits the cow's appetite and energy metabolism [19]. Blood thyroid hormones' concentrations (T3 and T4) are also affected by heat stress. Blood concentrations of T3 and T4 are decreased in cows that are subjected to heat stress, since lowered thyroid hormone levels reduce heat production, which helps the body adapt to warmer environments [20].

The aim of this study was to use evaporative cooling to reduce the high environmental temperature, and its detrimental effects on rectal temperature and thyroid hormones in dairy Holstein cows in the semi-arid environment of the Riyadh region in Saudi Arabia.

\section{Materials and Methods}

The Faculty Research Ethics Committee at King Saud University approved all procedures in this experiment. Twelve Holstein dairy cows in a dairy farm in the Riyadh region were used. Cows were randomly divided into two groups of six. All cows were cycling, milked twice daily and at least 45 days postpartum.

The experiment period was during the hottest months of the year in Saudi Arabia, July and August. Cows were kept for 2 weeks under open shade without evaporative cooling for acclimatization before the beginning of the experiment, which lasted for 22 days. One group was kept under shade without cooling (shade only group), and the other was kept under shade plus (spraying) evaporative cooling (evaporative cooling group). Evaporative cooling was applied throughout the day (8:00 to 20:00).

Environmental temperatures were measured daily using a data logger (Poket Logger, Pace Scientific Inc., North Carolina, USA), recording the highest and lowest temperatures. In addition, rectal temperatures were measured using a digital thermometer (Citizen Systems Japan Co, Ltd). THI was used to estimate the environmental severity, which was calculated using the following adapted equation: $\mathrm{THI}=\mathrm{Tdb}\left(\right.$ in $\left.{ }^{\circ} \mathrm{C}\right)+0.36 * \mathrm{Tdp}$ (in ${ }^{\circ} \mathrm{C}$ ) +41.2 [21]. This formula uses dry bulb temperature $\left(\mathrm{Tdb},{ }^{\circ} \mathrm{C}\right)$ and relative humidity $(\mathrm{RH})$. The $\mathrm{RH}$ is divided by 100 to express the percentage in decimals.

All cows were provided with water at libitum and fed according to the National Research Council [22] protocols for dairy cattle. Blood samples were collected daily from each cow via coccygeal venipuncture into vacutainer tubes (Becton, Dickinson and Company, New Jersey, USA). All samples were immediately placed on ice and transported to the laboratory. Serum was separated by centrifugation at $3,000 \mathrm{rpm}$ for $30 \mathrm{~min}$ at $4^{\circ} \mathrm{C}$, transferred into $1.5 \mathrm{ml}$ Eppendorf tubes and stored at $-20^{\circ} \mathrm{C}$ until being assayed for T3 and T4. Samples were analyzed in duplicate in the same assay using an ELISA kit (Kayman Pharm, Czech Republic).

Data were statistically analyzed using the general linear model (GLM) procedure of Statistical Analysis System (SAS, Inst. Inc., Cary, NC, USA) to determine the effects of evaporative cooling on environmental, rectal temperature, T3 and $\mathrm{T} 4$, and relative humidity and THI.

\section{Results}

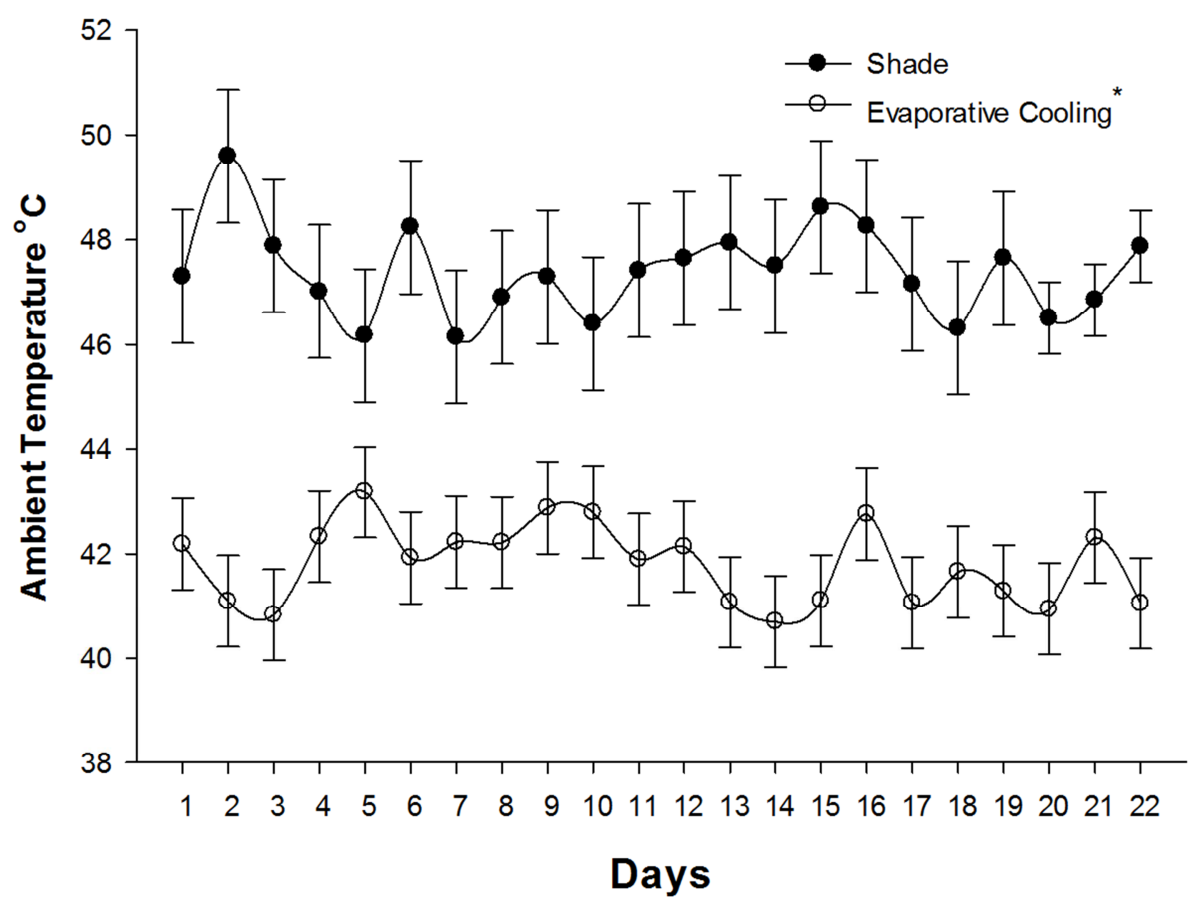

Figure 1. Ambient temperature $\left({ }^{\circ} \mathrm{C}\right)$ under shaded only and evaporative cooling conditions (means $\pm S E$ ). * indicates significant difference at P<0.05. 


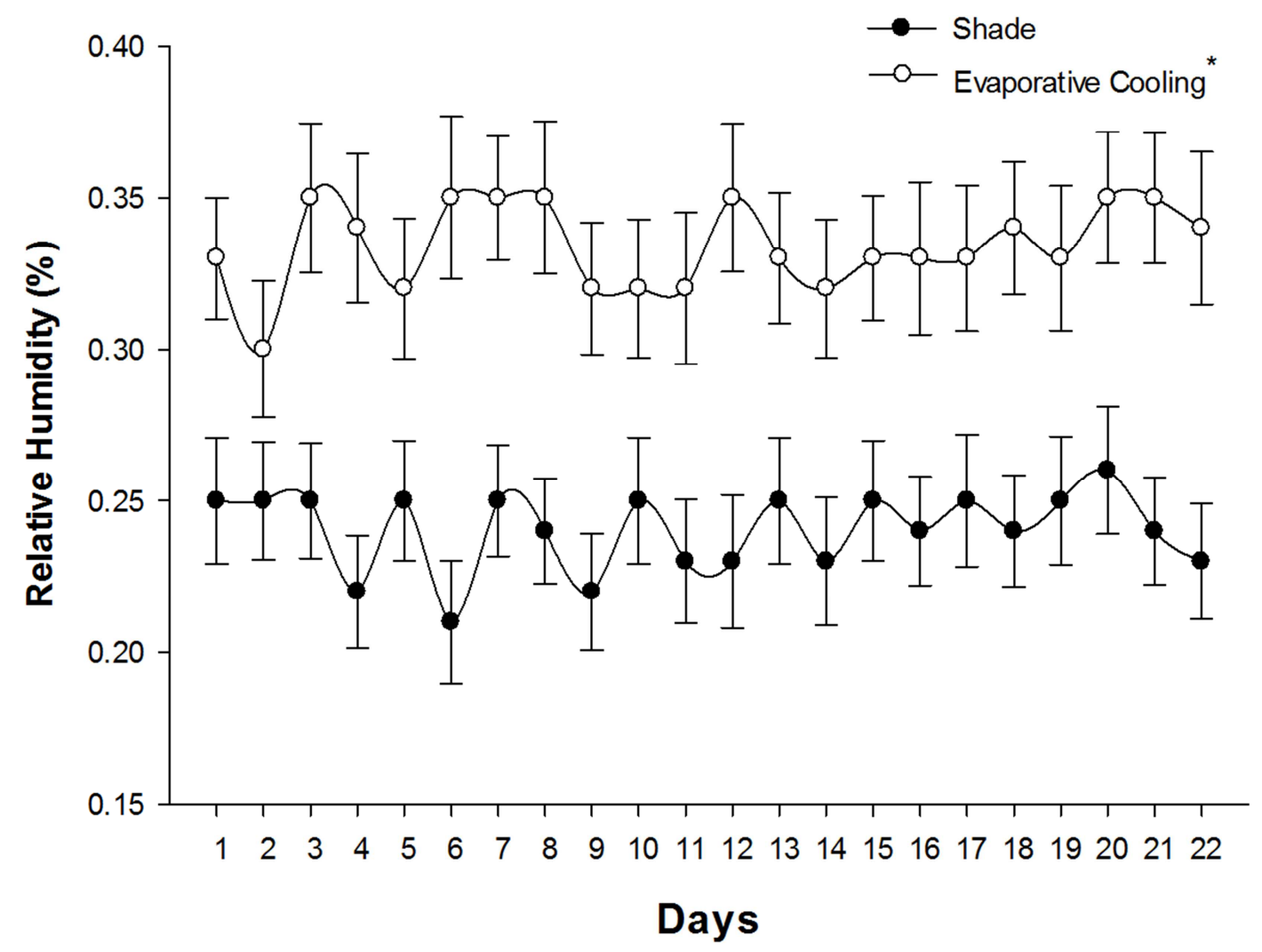

Figure 2. Relative humidity under shade only and evaporative cooling conditions (means $\pm S E$ ). * indicates significant difference at $P<0.05$.

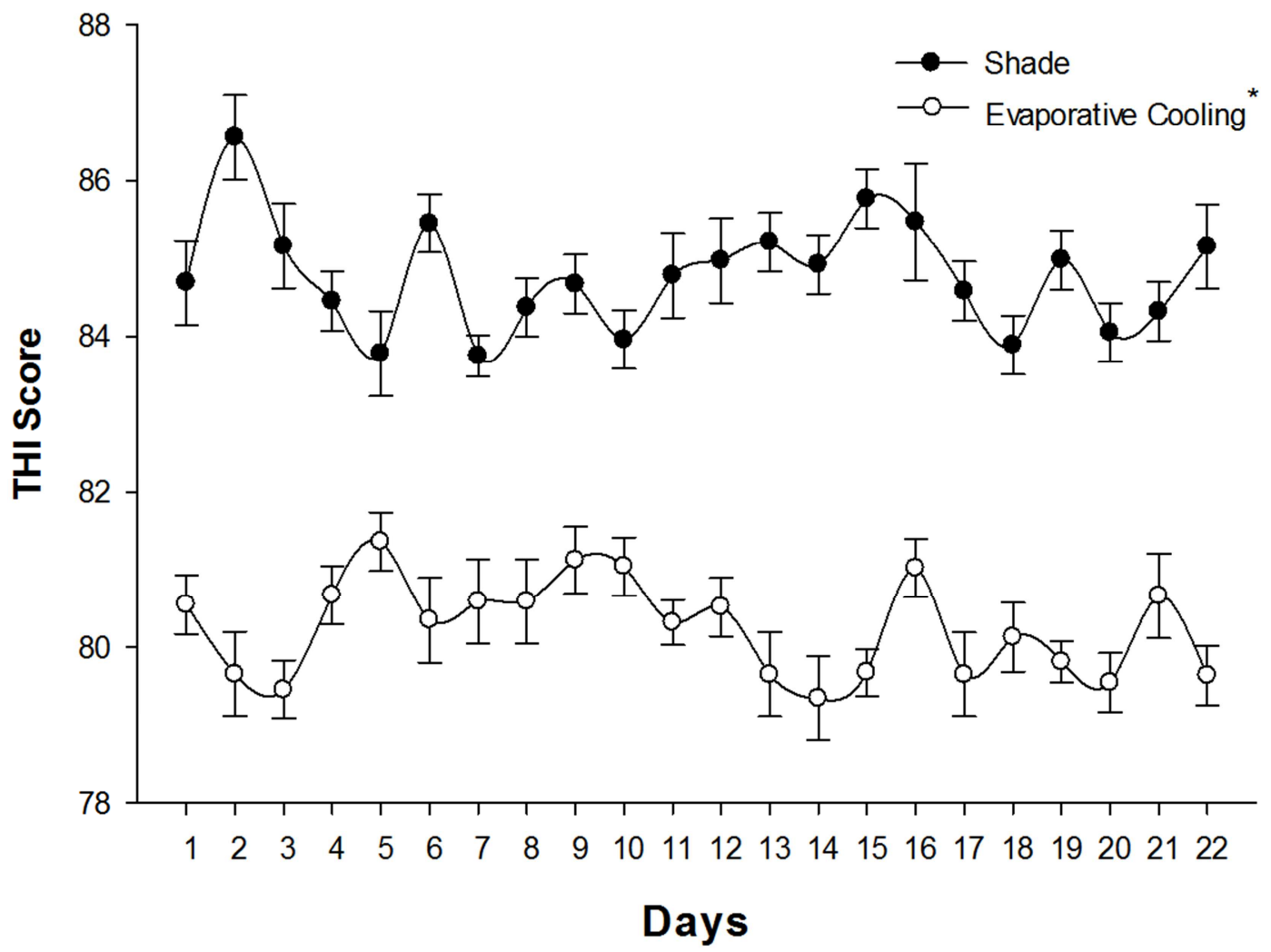

Figure 3. Temperature Humidity Index (THI) under shade only and evaporative cooling conditions (means \pm SE). * indicates significant difference at $P<0.05$.

Figure 4 shows the average rectal temperature in cows during the experimental period. Rectal temperature was lower for the evaporative cooling group $\left(38.4 \pm 0.32^{\circ} \mathrm{C}\right)$ than the shade only cows $\left(39.53 \pm 0.44^{\circ} \mathrm{C}, \mathrm{p}<0.05\right)$. 


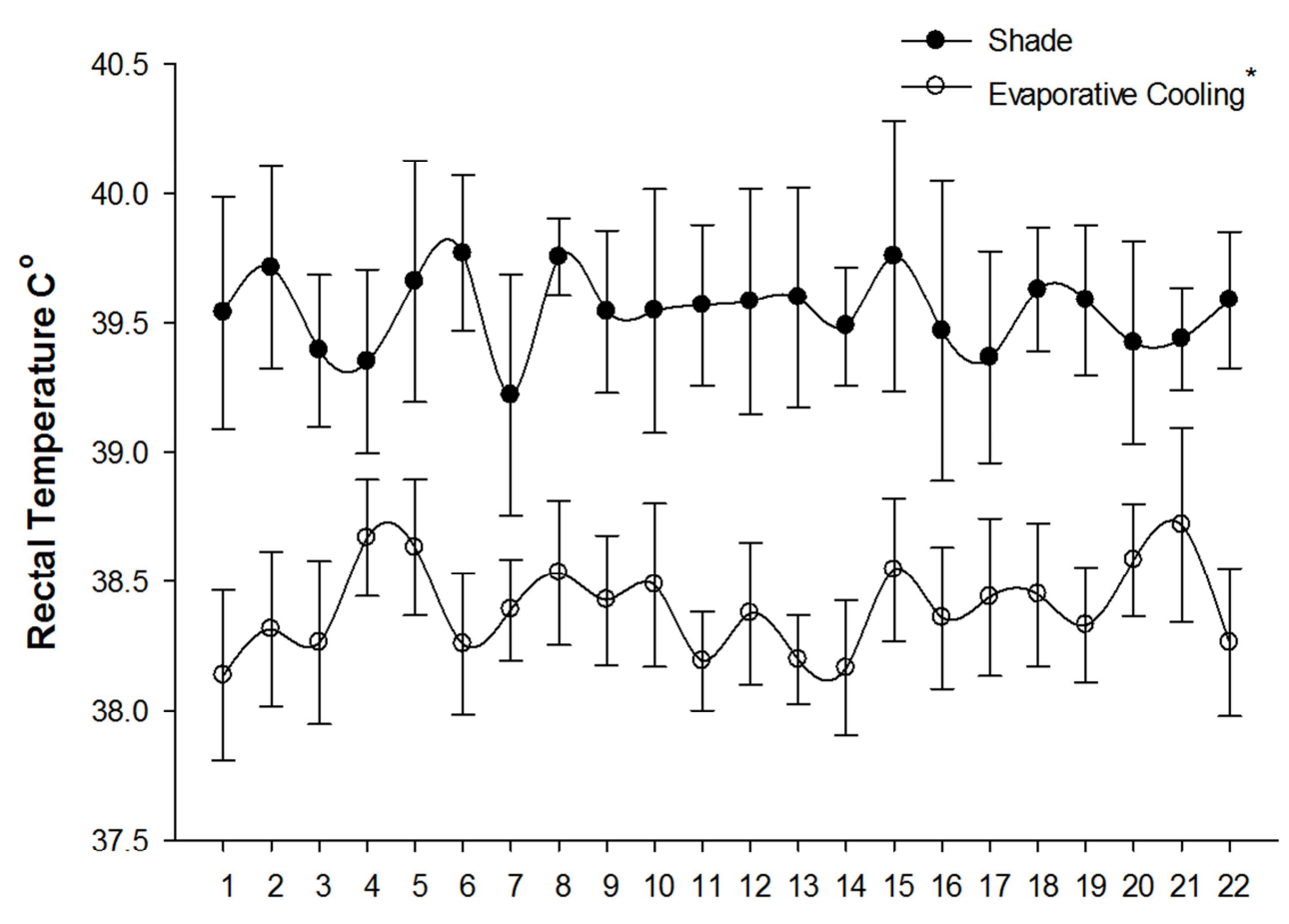

Days

Figure 4. Rectal temperature of cows under shade only and under evaporative cooling conditions (means $\pm S E$ ). * indicates significant difference at $P<0.05$.

Daily environmental parameters (AT, RH and THI) throughout the experiment period are shown in figures 1,2 and 3. In both groups (evaporative cooling and shade only), the environmental temperatures were high. Ambient temperature (AT) was lower in the evaporative cooling group than in the shade only group $(41.80 \pm 0.74$ vs. $47.40 \pm$ $\left.0.84^{\circ} \mathrm{C}, \mathrm{p}<0.05\right)$. RH was greater and THI was lower in the evaporative cooling than in the shade only group $(0.33 \pm 0.01$ vs $0.24 \pm 0.01$ and $80.24 \pm 0.60$ vs. $84.77 \pm 0.68$, respectively, both $\mathrm{p}<0.05$ ).

Figure 5 shows that $\mathrm{T} 3$ serum concentrations were lower $(p<0.05)$ in the shade group when compared to the evaporative cooling group $(0.75 \pm 0.20 \mathrm{ng} / \mathrm{ml}$ vs. $2.50 \pm$ 0.90 ). Figure 6 shows that T4 serum concentrations were lower $(\mathrm{p}<0.05)$ in the shade group, compared to evaporative cooling cows ( $7.22 \pm 1.88$ vs. $11.94 \pm 1.60)$.

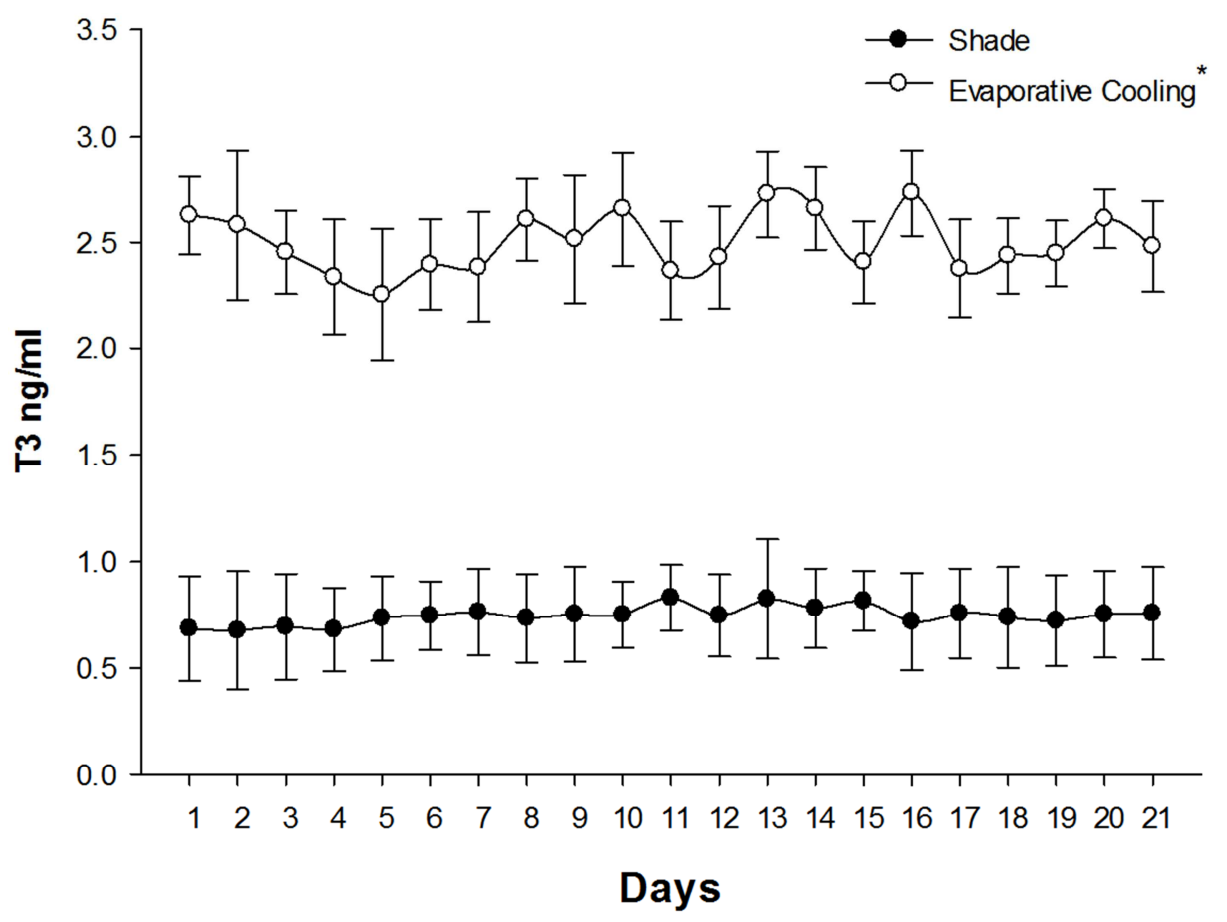

Figure 5. Serum T3 concentrations $(\mathrm{ng} / \mathrm{ml})$ of cows under shade only and under evaporative cooling conditions (means $\pm S E)$. indicates significant difference at $P<0.05$. 


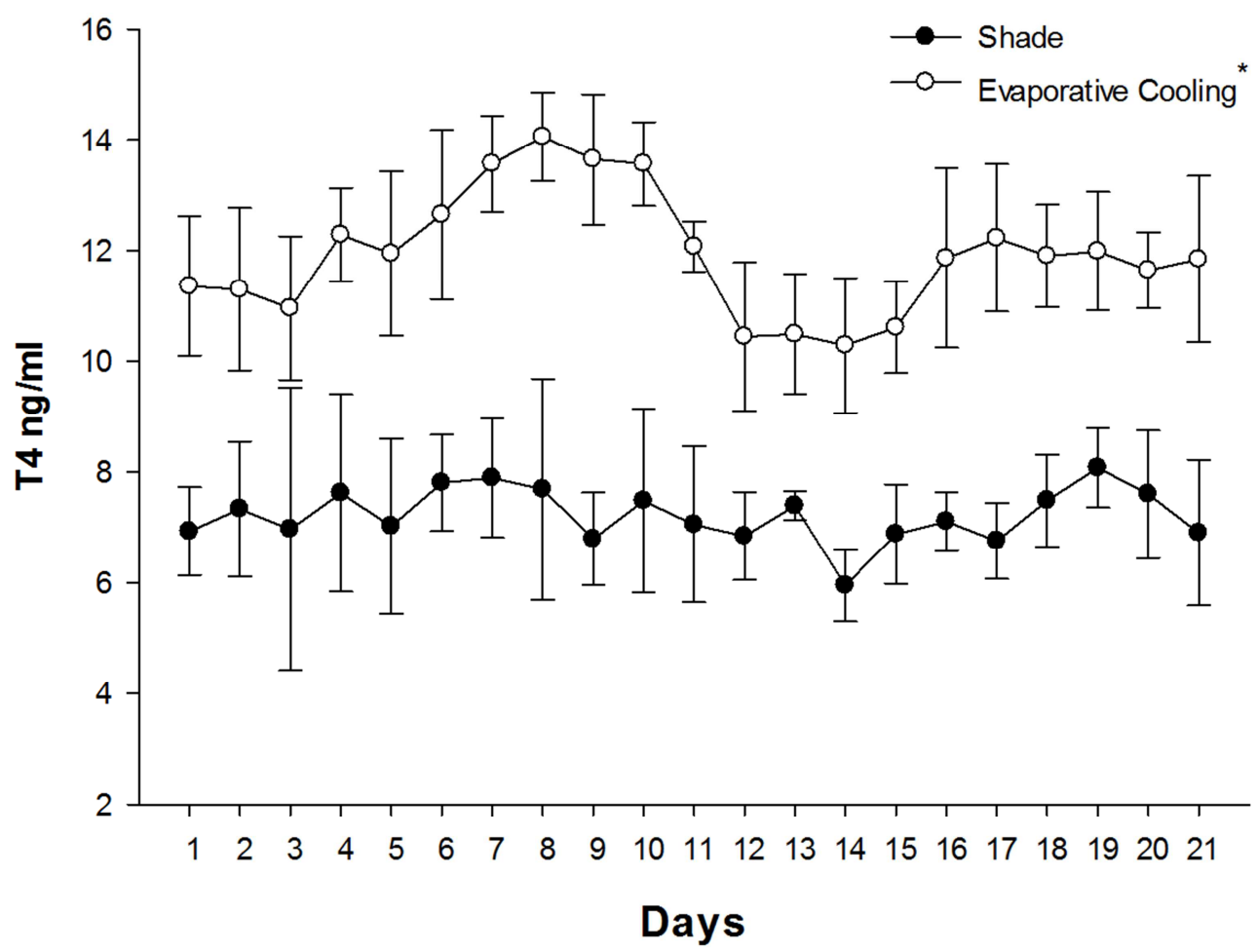

Figure 6. Serum T4 concentrations $(\mathrm{ng} / \mathrm{ml})$ of cows under shade only and under evaporative cooling conditions (means $\pm S E) . *$ indicates significant difference at $P<0.05$.

\section{Discussion}

The summer months in the Riyadh region, Saudi Arabia, are characterized by high temperatures and low humidity. Lactating dairy cows prefer ATs of between 10 and $25^{\circ} \mathrm{C}$, known as the thermoneutral zone [23]). Whenever AT is beyond these limits, cows are considered to be under heat stress, thus, milk production declines [24]. In addition, THI values of 70-72 units or less are considered acceptable [17], while a THI greater than 72 units causes a reduction in dry matter intake and milk production and composition manifested by having reduced fat, protein and casein contents in dairy cows $[14,25]$. In addition, a THI index of up to 84 was associated with reduction in triacylglycerol and polar lipid profiles [26]. Furthermore, an increased THI resulted in increased incidence of mastitis in cows [27]. Evaporative cooling significantly lowered AT $\left(41^{\circ} \mathrm{C}\right.$ vs $\left.47^{\circ} \mathrm{C}\right)$ and THI ( 80 vs 84 units), and increased $\mathrm{RH}$, compared to the shaded only group. Although AT and THI were lower in the evaporative cooling group, these values remain above the comfort zone for dairy animals.

Desert environments are characterized by fluctuations in temperature between day and night [2]. The high daytime temperatures in desert environments raise animal body temperatures due to inadequate evaporative heat loss, which leads to increased heat production by the animal [28]. When the evaporative heat loss ability (through sweating and panting) is less than the thermal load of the animal, fluid loss reaches a critical level, body temperature rises, and the animal may die from hyperthermia [29]. These effects account for the lower milk production and fertility of dairy farms during the summer season, even with the use of advanced environmental modifications to alleviate heat stress [4].

Animals can cope with environmental temperature changes by stabilizing their body temperature within certain limits. Body temperature is susceptible to increased environmental temperatures and can be used to estimate heat stress [24]. In addition, there are significant relationships between rectal temperature, skin temperature, respiratory rate and milk production [30]. Normal rectal temperature in dairy cows ranges from 38 to $39.3^{\circ} \mathrm{C}$ during the whole year [31]. When rectal temperature reaches $39^{\circ} \mathrm{C}$, high producing cows in early lactation show a sharp decline in milk production, since these cows are more susceptible to heat stress than low producing cows [32]. Our results indicate that, although cows under evaporative cooling have decreased rectal temperature compared to cows under shade only, evaporative cooling was unable to completely ameliorate heat stress. In fact, rectal temperature was higher than the optimal, even in cows under evaporative cooling. These high rectal temperatures, even under evaporative cooling, could be due to the low efficiency of the evaporative cooling system practiced in the farm during the trial period, since no barn side shades were installed at the time.

Dairy cows are known to have low T3 and T4 in their blood during the summer, or when under heat stress, and high $\mathrm{T} 3$ and T4 concentrations during the winter [32]. Thus, changes in climatic situations (e.g., shade and cooling) are expected to affect the animal's thyroid activity [33]. Cows under heat stress lower their metabolic activities, and thus their heat production [34]. In our experiment, all cows were 
kept for two weeks under shade without evaporative cooling for acclimatization, since the response of $\mathrm{T} 3$ and $\mathrm{T} 4$ to heat stress is slow [35]. Our T3 and T4 data for shaded only and evaporative cooling cows are in line with previous studies; $\mathrm{T} 3$ and $\mathrm{T} 4$ are lower in more heat stressed cows. However, in this study, all cows, including those under evaporative cooling, were under some degree of heat stress.

This study sheds light on the effects of evaporative cooling on dairy cows during the summer under a semi-arid environment, where AT is extremely high. Cows that produce little milk or do not become pregnant are usually culled, and heat stress is known to negatively affect reproductive performance of dairy cows. Our data show that, in arid and semi-arid regions (e.g., central Saudi Arabia), while heat stress cannot be eliminated, its detrimental effects on productive and reproductive performance can be lowered. Evaporative cooling lowered the AT around the animals, which reduced rectal temperature and affected $\mathrm{T} 3$ and $\mathrm{T} 4$ serum concentrations.

\section{Conclusion}

The results of this study showed that evaporative cooling, even without fans, lowers ambient and rectal temperatures. In addition, evaporative cooling increased serum concentrations of T3 and T4, which are used as a heat stress indicators. Evaporative cooling has a positive effect on dairy cows performance as a whole, and this study for the first time shows the effect of evaporative cooling during the estrous cycle under semi-arid environment in Riyadh, Saudi Arabia.

\section{Conflict of Interest}

The authors declare that they have no competing interests.

\section{References}

[1] Zell, E., Gasim, S., Wilcox, S., Katamoura, S., Stoffel, T., Shibli, H., Engel-Cox, J., Al Subie, M., 2015. Assessment of solar radiation resources in Saudi Arabia. Solar Energy, 119, 422-438.

[2] Presidency of Meteorology and Environment PME, 2006. Meteorological data of Riyadh for the period 1985-2005, PME, Jeddah, Saudi Arabia.

[3] Al-Haidary A, Aljumaah, R. S., Alshaikh, M. A., Abdoun, K. A., Samara, E. M., Okab, A. B., Alfuraiji, M. M., 2012. Thermoregulatory and physiological responses of najdi sheep exposed to environmental heat load prevailing in Saudi Arabia. Pakistan Veterinary Journal. 32, 515-519.

[4] Al-Hassan, M. J., 2002. The adequacy of existing environmental modification for eliminating seasonal reduction in reproductive performance of dairy cattle under a semi-arid environment in Central Saudi Arabia. Zagazig Veterinary Journal. 3, 165-173.

[5] St-Pierre, N. R., Cobanov, B., Schnitkey, G., 2003. Economic Loss from Heat Stress by U.S. Livestock Industries. Journal of Dairy Science E Suppl. 86, E52-E77.
[6] Kadzere, C., Murphy, M., Silanikove, N., Maltz, E., 2002. Heat stress in lactating dairy cows, A Review. Livestock Production Science 77, 59-91.

[7] Srikandakumar, A., Johnson, E. H., 2004. Effect of heat stress on milk production, rectal temperature, respiratory rate and blood chemistry in Holstein, Jersey and Australian Milk Zebu cows. Tropical Animal Health Production. 36, 685-692.

[8] Bewley, J. M., Einstein, M. E., Grott, M. W., and Schutz, M. M., 2008. Comparison of reticular and rectal core body temperatures in lactating dairy cows. Journal of Dairy Science. 91, 4661-4672.

[9] Takahashi, M., 2012. Heat stress on reproductive function and fertility in mammals. Reproductive Medicine and Biology, 11, 37-47.

[10] Dash, S., Chakravarty, A. K., Singh, A., Upadhyay, A., Singh, M., Yousuf, S., 2016. Effect of heat stress on reproductive performances of dairy cattle and buffaloes, A review. Veterinary World, 9, 235-244.

[11] Wolfenson, D., Roth, Z., Meidan, R., 2000. Impaired reproduction in heat-stressed cattle: basic and 387 applied aspects. Animal reproduction science, 60-61, 535-547.

[12] Honig, H., Ofer, L., Kaim, M., Jacobi, S., Shinder, D., Gershon, E., 2016. The effect of cooling management on blood flow to the dominant follicle and estrous cycle length at heat stress. Theriogenology, 15, 626-634.

[13] Nardone, A., Ronchi, B., Lacetera, N., Ranieri, M. S., Bernabucci, U., 2010. Effects of climate changes on animal production and sustainability of livestock systems. Livestock Science, 130, 57-69.

[14] Cowley, F. C., Barber, D. G., Houlhan, A. V., Poppi, D. P., 2015. Immediate and residual effects of heat stress and restricted intake on milk protein and casein composition and energy metabolism. Journal of Dairy Science, 98, 2356-2368.

[15] Silva, C. F., Sartorelli, E. S., Castilho, A. C. S., Satrapa, R. A., Puelker, R. Z., Razza, E. M., Ticianelli, J. S., Edurado, H. P., Loureiro, B., Barros, C. M., 2013. Effects of heat stress on development, quality and survival. Theriogenology. 2, 351357.

[16] Schuller, L.-K., Bureind, O., Heuwieser, W., 2016. Effect of short- and long-term heat stress on the conception risk of dairy cows under natural service and artificial insemination breeding programs. Journal of Dairy Science. 99, 2996-3002.

[17] Gantner, V., Mijic, P., Kuterovac, K., Solic, D., Gantner, R., 2011. Temperature-humidity index values and their significance on the daily production of dairy cattle. Mljekarstvo, 61, 56-63.

[18] Knapp, D. M. and Grummer, R. R., 1991. Response of lactating dairy cows to fat supplementation during heat stress. Journal of Dairy Science. 74, 2573-2579.

[19] Zhang, L., Ying, S. J., An, W. J., Lian, H., Zhou, G. B., and Han, Z. W., 2014. Effect of dietary betaine supplementation subjected to heat stress on milk performances and physiology indices in dairy cows. Genetic and Molecular Research. 13, 7577-7586.

[20] De Guia, R. M., A. J. Rose and S. Herzig, 2014. Glucocorticoid hormones and energy homeostasis. Hormone molecular biology and clinical investigation, 19, 117-128. 
[21] Armstrong, D. V., 1994. Heat stress interaction with shade and cooling. Journal of Dairy Science. 77, 2044-2050.

[22] National Research Council, 2001. Nutrient requirements of dairy cattle $7^{\text {th }}$ edition. National Academic Press, Washington DC.

[23] Noordhuizen, J., Bonnefoy, J. M., 2015. Heat Stress in Dairy Cattle: Major Effects and Practical Management Measures for Prevention and Control. SOJ Veterinary Science, 1, 1-7.

[24] Das, R., Sailo, L., Verma, N., Bharti, P., Saikia, N., Imtiwati, Rakesh Kumar, R., 2016. Impact of heat stress on health and performance of dairy animals: A review. Veterinary World, 9, 260-268.

[25] Pragna, P., Archana, P. R., Aleena, J., Sejian, V., Krishnan, G., Bagath, M., Manimaran, A., Beena, V., Kurien, E. K., Varma, G., Bhatta, R., 2017. Heat Stress and Dairy Cow, Impact on Both Milk Yield and Composition. International Journal of Dairy Science, 12, 1-11.

[26] Liu, Z., Ezenrnieks, V., Wang, J., Arachillage, N. W., Garner, J. B., Wales, W. J., Cocks, B. G., Rochfort, S., 2017. Heat Stress in Dairy Cattle Alters Lipid Composition of Milk. Scientific Reports, 7, 961.

[27] Jingar, S. C., Mehla, R. K., Singh, M., 2014. Climatic effects on occurrence of clinical mastitis in different breeds of cows and buffaloes. Archivos de Zootecnia. 63, 473-482.

[28] Polsky, L., von Keyserling, M. A. G., 2017. Effects of heat stress on dairy cattle welfare. Journal of dairy science, 100, 8645-8657.
[29] Shilja, S., Sejian,. V, Bagath, M., Mech, A., David, C. G., Kurien, E. K., Varma G., Bhatta, R., 2016. Adaptive capability as indicated by behavioral and physiological responses, plasma HSP70 level, and PBMC HSP70 mRNA expression in Osmanabadi goats subjected to combined (heat and nutritional) stressors. International Journal of Biometeorology, 60, 1311-1323.

[30] Kou, H., Zhao, Y., Ren, K., Chen, X., Lu, Y., Wang, D., 2017. Automated measurement of cattle surface temperature and its correlation with rectal temperature. PLoS One, 12, 1-10.

[31] Schutz, M. M., Bewley, J. M., 2009. Implications of changes in core body temperature. Tri-State Dairy Nutrition Conference. 35-54.

[32] Aleena, J., Pragna, P., Archana, P. R., Sejian, V., Bagath, M., Krishnan, G., Manimaran, A., Beena, V., Kurien, E. K., Varma, G., Bhatta, R., 2016. Significance of Metabolic Response in Livestock for Adapting to Heat Stress Challenges. Asian Journal of Animal Sciences, 10, 224-234.

[33] Aggarwal, A., Singh, M., 2009. Changes in hormonal levels during early lactation in summer calving cows kept under mist cooling system. Indian Journal of Animal Nutrition. 26, 337340 .

[34] Horowitz, M., 2001 Heat acclimation, phenotypic plasticity and cues to the underlying molecular mechanism. Journal of Thermal Biology. 26, 357-363.

[35] Silanikove, N., 2000. Effects of heat stress on the welfare of extensively managed domestic ruminants. Livestock Production Science. 67, 1-18. 